\title{
Analisis Unjuk Kerja FBMC-OQAM Pada Transmisi Citra QR Code Menggunakan Ekualisasi Zero Forcing
}

\author{
Brayan Raynaldi, Anggun Fitrian Isnawati* dan Mas Aly Afandi \\ Institut Teknologi Telkom Purwokerto \\ *Corresponding author, e-mail: anggun@ittelkom-pwt.ac.id
}

\begin{abstract}
Abstrak - Aplikasi komunikasi nirkabel di masa depan menuntut pelayanan data rate yang tinggi dan spektrum yang efisien. Untuk dapat menyediakan laju bit yang tinggi dapat menggunakan modulasi jamak atau multicarrier. Penggunaan modulasi FBMC OQAM bertujuan memberikan peningkatan unjukkerja dibandingkan dengan modulasi sebelumnya yakni OFDM, hal ini karena penggunaan FBMC dengan sifat orthogonalitasnya dan penggunaan OQAM yang memiliki keunggulan lebih kuat terhadap efek dispersi serta memiliki kecepatan data yang tinggi. Untuk mendapatkan sinyal informasi yang dikirimkan, digunakan ekualisasi ZF (Zero Forcing). Hasil simulasi menunjukkan FBMC OQAM dengan ZF dapat menurunkan BER dari nilai 0,4275 pada SNR $0 \mathrm{~dB}$ menjadi 0,01231 pada SNR $25 \mathrm{~dB}$. Sedangkan pada FBMC OQAM tanpa ZF memiliki nilai BER 0,513 pada SNR 0 dB menjadi 0,5212 pada SNR $25 \mathrm{~dB}$. Hal ini menunjukkan bahwa FBMC OQAM menggunakan ZF mempunyai nilai BER yang lebih rendah dibandingkan FBMC OQAM tanpa ZF.
\end{abstract}

Kata Kunci : FBMC, OQAM, ZF, SNR, BER

\begin{abstract}
Wireless communication applications in the future require high data rate and efficient spectrum services. To be able to provide a high bit rate we can use plural modulation or multicarrier. The use of FBMC OQAM modulation aims to provide increased performance compared to the previous modulation, namely OFDM, this is due to the use of FBMC with its orthogonality properties and the use of OQAM which has a stronger advantage over the dispersion effect and has a high data rate. To get the information signal issued, ZF (Zero Forcing) equalization is used. Simulation results show that FBMC OQAM with ZF can reduce BER from 0.4275 at SNR $0 \mathrm{~dB}$ to 0.01231 at SNR $25 \mathrm{~dB}$. Whereas the OQAM without ZF FBMC has a BER value of 0.513 at SNR $0 \mathrm{~dB}$ to 0.5212 at SNR $25 \mathrm{~dB}$. This shows that the FBMC OQAM using ZF has a lower BER value than the FBMC OQAM without ZF.
\end{abstract}

Keywords : FBMC, OQAM, ZF, SNR, BER

\section{Pendahuluan}

Perkembangan dunia komunikasi terus mengalami kemajuan yang pesat. Termasuk didalamnya perkembangan komunikasi nirkabel bergerak. Dengan perkembangan ini permintaan dan kebutuhan akan layanan data rate yang besar, voice serta data menjadi semakin meningkat. Sementara untuk mencapai data rate yang tinggi juga membutuhkan bandwidth yang besar juga [1]. Untuk mengatasi hal ini diperlukan teknik multicarrier, karena dengan menggunakan multicarrier bandwidth yang tersedia di spektrum akan dibagi menjadi beberapa sub band. Salah satu bentuk dari transmisi multicarrier adalah OFDM (Orthogonal Frequency Division Multiplexing). OFDM memiliki beberapa keunggulan yaitu kecepatan transmisi yang tinggi dengan menggunakan sinyal pembawa secara paralel, selain itu jarak yang sempit, bahkan hingga saling overlap sehingga pada akhirnya akan menghemat kebutuhan bandwidth [2].

Namun dari beberapa keunggulan yang ada pada OFDM, OFDM juga memiliki kelemahan di antaranya mudah terkontaminasi oleh distorsi linear [3]. Maka dari itu untuk mengatasi kelemahan ini diperlukan teknologi baru yang dinamakan FBMC (Filter Bank Multicarrier) dengan modulasi OQAM (Offset Quadrature Modulation) dalam penghematan bandwidth [3]. FBMC merupakan pola gelombang yang paling menjanjikan untuk jaringan nirkabel di masa depan khususnya komunikasi 5G [4]. Sementara penggunaan modulasi digital yang paling banyak menggunakan QAM (Quadrature Amplitude 
Modulation) karena memiliki banyak kelebihan seperti efisien dalam penggunaan bandwidth, tetapi di sisi lain QAM memiliki kelemahan yaitu decision yang rumit serta data rate yang rendah. Untuk mengatasi hal ini QAM dikembangkan menjadi OQAM (Offset Quadrature Modulation) yang memiliki kestabilan sistem yang lebih baik dari pada QAM [5]. Dengan menggunakan skema O-QAM, spektrum saluran yang berdekatan saling tumpang tindih tanpa menyebabkan crosstalk antar subcarrier karena adanya penundaan simbol half time antara komponen dalam fasa dan sinyal kuadrat pada setiap subcarrier [6]. Pengurangan jarak kanal yang berdekatan pada subcarrier yang dapat mengurangi efek dari ICI (Intercarrier Interference) maupun ISI (Inter Symbol Interference) [7]. Penggunaan OQAM tidak hanya memperbaiki kinerja pada sistem OFDM dan FBMC, tetapi pada GFDM yang menggunakan OQAM juga mampu meningkatkan kinerja secara signifikan [8].

Pada transmisi pengiriman data dari pengirim dan penerima pasti tidak akan sama. Hal ini dikarenakan pada proses transmisi sinyal yang dikirim akan bercampur dengan derau. Begitu juga dengan data masukan citra, dimana derau akan bisa terlihat dari sisi bentuk citra yang diterima. Untuk mengatasi ini memerlukan algoritma deteksi simbol yang handal dalam mendeteksi simbol asli yang dikirimkan. Adapun jenis algoritma deteksi simbol salah satunya adalah Zero Forcing (ZF). Algoritma ini yang paling sederhana dibandingkan dengan algoritma yang lain [6][9].

Kode QR sebagai citra digital 2 dimensi mampu dideteksi oleh citra semikonduktor dan dianalisis secara digital oleh prosesor terprogram. Prosesor menempatkan tiga kotak khusus di sudut gambar dan menggunakan kotak yang lebih kecil di dekat sudut keempat untuk menormalkan gambar berdasarkan ukuran, orientasi dan sudut pandang. Titik-titik kecil tersebut kemudian diubah menjadi bilangan biner dan divalidasi dengan kode koreksi kesalahan [10]. Keunggulan kode QR dibandingkan dengan kode batang adalah fungsional, yang karena kepadatan data yang lebih tinggi dari proses kode (lebih dari 100 kali lipat dari barcode), kode QR dapat berisi lebih banyak informasi daripada barcode ketika menempati slot ruang sebanyak (hampir 7000 alfa numerik per karakter), dan yang kedua mampu mendukung pengkodean karakter seperti yang digunakan pada grafik logo dan sistem fonemik [11].

Pada penelitian ini menggunakan citra $\mathrm{QR}$ code karena citra QR code memiliki kode tersembunyi di dalamnya. Penelitian ini menguji apakah dengan pengiriman data pada komunikasi FBMC berpengaruh pada citra yang diterima di sisi penerima baik yang menggunakan ekualisasi ataupun yang tanpa ekualisasi $\mathrm{ZF}$, berdasarkan parameter bit error rate (BER).

\section{Sistem Model}

Tahap awal pemodelan sistem simulasi dapat ditunjukkan pada Gambar 1. Proses tahapan simulasi dibedakan menjadi dua, yaitu pada sisi pengirim dan penerima. FBMC terdiri dari 2 proses utama yakni sintesis bank filter yang berada pada sisi pengirim dan analisis bank filter yang berada pada sisi penerima.

Pada penelitian ini akan difokuskan pada bagaimana kinerja FBMC yang paling sederhana dalam proses komunikasi data berupa citra atau gambar, dengan menggunakan ekualisasi Zero Forcing. Parameter penelitian yang digunakan adalah BER (Bit Error Rate) atau laju galat bit, SNR (Signal to Noise Ratio) perbandingan sinyal terhadap noise, SER (Simbol Error Rate), dan kapasitas kanal. Selain dilakukan pengujian dengan menggunakan parameter tersebut, pengujian juga dilakukan dengan menggunakan aplikasi scan $Q R$ Code karena data masukan yang digunakan adalah citra $Q R$ Code. Hal ini dilakukan untuk mengetahui pada nilai SNR berapakah data tersebut dapat dibaca dan sesuai dengan informasi data masukannya.

\section{Metodologi}

\subsection{Filter Bank Multicarrier}

Teknik modulasi yang paling umum digunakan adalah OFDM (Orthogonal Frequency Division Multiplexing) karena memiliki keunggulan dibandingkan modulasi yang lainnya. Namun selain itu, OFDM juga memiliki kekurangan, salah satunya penggunaan cyclix prefix. Sebagai Teknik modulasi baru, FBMC diciptakan untuk mengatasi kekurangan dari OFDM [1].

Pada FBMC terdapat dua proses di dalamnya. Proses pertama adalah pra pemrosesan atau dinamakan Sintesis Bank Filter, dan proses kedua adalah pasca pemrosesan atau dinamakan Analisis Bank Filter. 

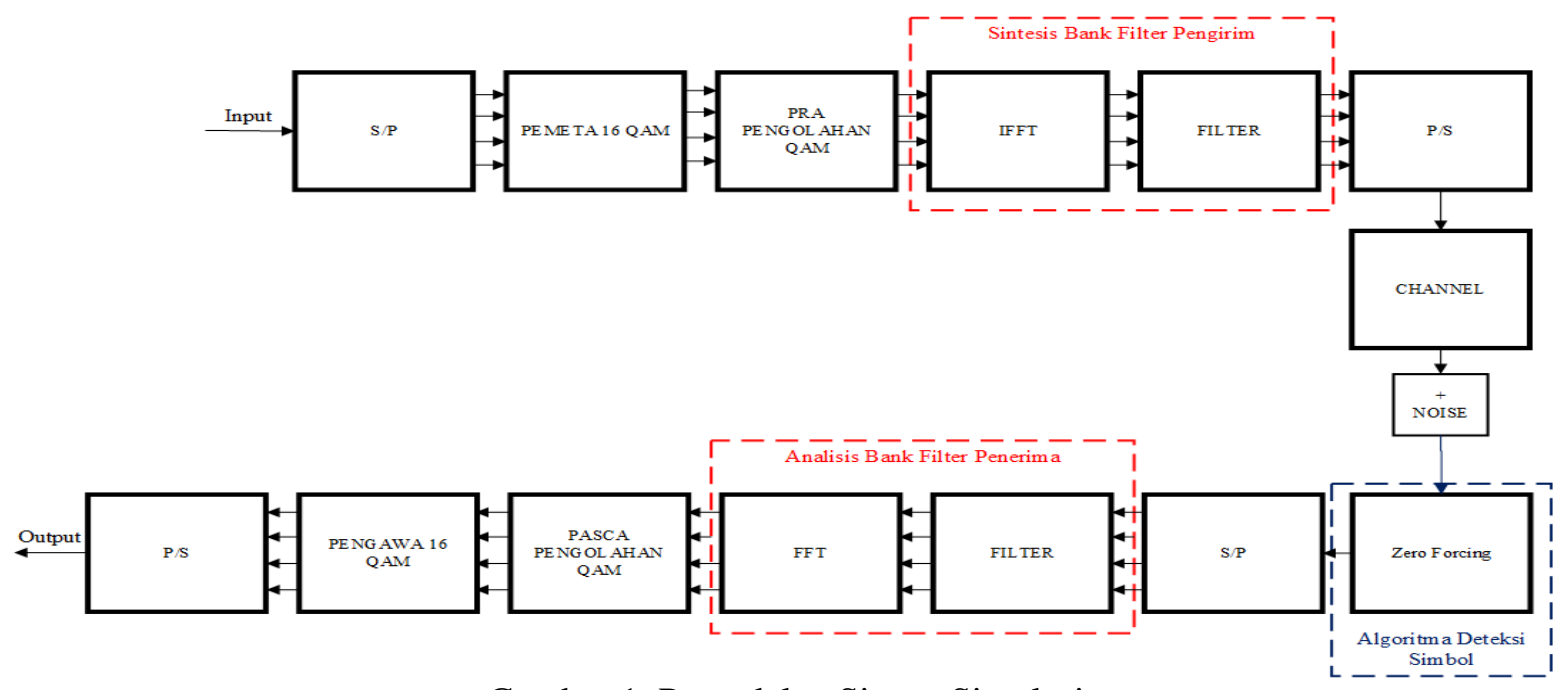

Gambar 1. Pemodelan Sistem Simulasi

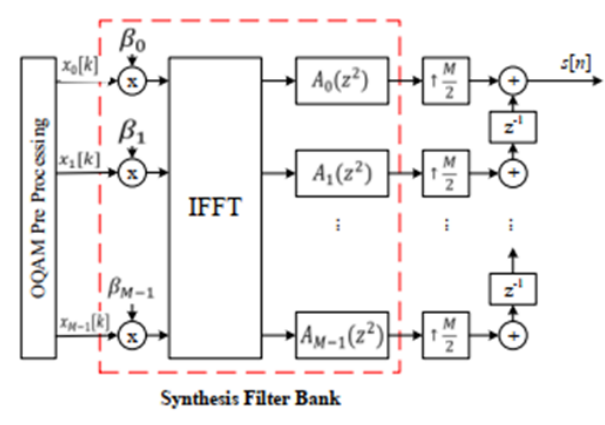

Gambar 2. Blok Diagram Sintesis Bank Filter FBMC [5]

Sintesis bank filter sebagaimana yang ditunjukkan pada Gambar 2 berada pada sisi transmitter. Proses didalamnya terdiri dari IFFT dan PPN. IFFT merupakan algoritma untuk mengkonversi dari domain frekuensi menjadi domain waktu. Sementara PPN (Poly Phase Network) merupakan jenis filter yang digunakan.

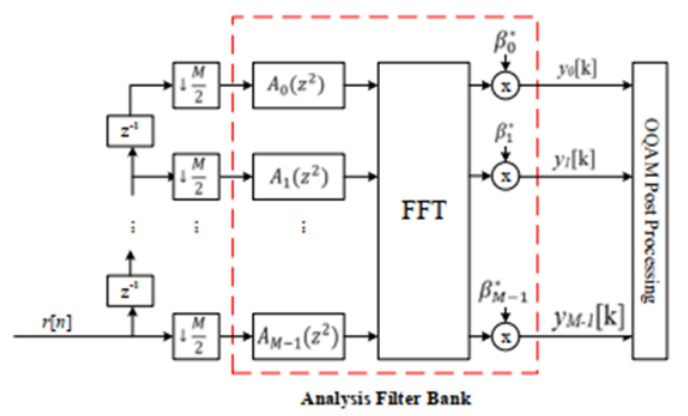

Gambar 3. Blok Diagram Analisis Bank Filter FBMC [5]
Filter ini memberikan lokalisasi yang baik dalam domain waktu untuk mengurangi intersymbol interference (ISI) dan domain frekuensi untuk mengurangi mengurangi inter carrier interference (ICI). Sementara analisis bank filter merupakan proses kebalikan dari proses Sintesis. Analisis ditempatkan pada sisi penerima atau receiver dan ditunjukkan pada Gambar 3.

\subsection{OQAM (Offset-QAM)}

Berbeda dengan modulasi QAM, pada modulasi OQAM memungkinkan spektrum kanal yang berdekatan terjadi overlap tanpa mengakibatkan crosstalk antar subcarrier yang disebabkan penundaan setengah simbol waktu antara inphase dan quadrature [12]. Pada modulasi offset QAM, terjadi pergeseran fasa yang dibatasi hingga $0^{\circ}$ dan $\pm 90^{\circ}$ setiap $t$ detik, tidak seperti pada QAM yang terjadi lompatan fasa hingga $180^{\circ}$. OQAM terdiri dari dua proses yaitu pra pengolahan dan pasca pengolahan.

\section{Pra Pengolahan OQAM}

Pada penelitian ini menggunakan data masukan citra kemudian akan mengalami proses modulasi 16-QAM untuk membentuk bilangan kompleks. Proses ini disebut juga proses mapping. Bilangan kompleks tersebut kemudian menjadi masukan untuk proses pra pengolahan OQAM sebagaimana yang ditunjukkan pada Gambar 4. Pra pengolahan akan membedakan bilangan riil dan imajiner dan akan dikirimkan berdasarkan simbol odd (ganjil) dan simbol even (genap) sesuai urutan mapping [13]. 
Pada pra pengolahan OQAM, simbol akan dibentuk menjadi bilangan kompleks serta akan dibedakan antara simbol even (genap) dan simbol odd (ganjil). Masing-masing simbol akan dikenakan perkalian faktor sebanyak 2 kali (upsampling). Pada sisi simbol even (genap), bilangan imajiner akan mengalami delay $\left(z^{-1}\right)$ sementara sebaliknya simbol odd (ganjil), bilangan riil yang akan dikenai delay $\left(z^{-1}\right)$. Penggunaan delay ini dimaksudkan untuk mencegah adanya interferensi antar simbol yang dikirimkan.

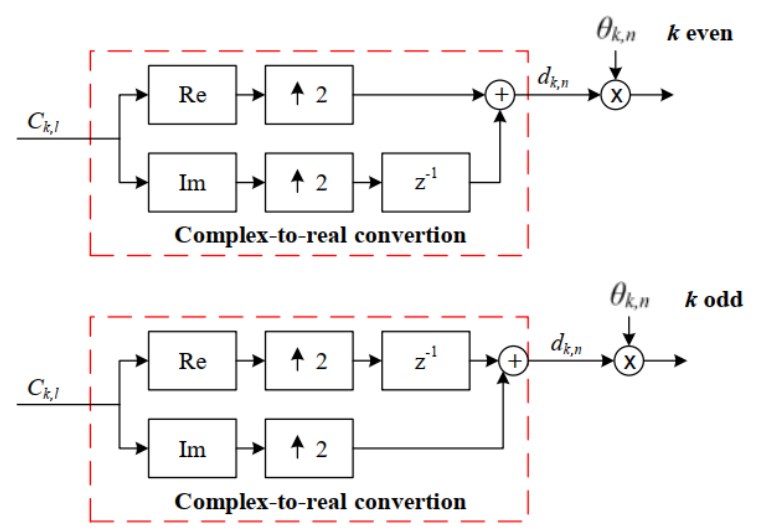

Gambar 4. Pra Pengolahan OQAM [13]

\section{Pasca Pengolahan OQAM}

Proses kedua ditunjukkan pada Gambar 5 merupakan proses pasca pengolahan OQAM. Pasca pengolahan adalah kebalikan dari proses pra pengolahan. Bilangan riil dari masing-masing simbol akan dikenakan penurunan faktor 2 kali (downsampling). Untuk membentuk kembali bilangan kompleks akan dikalikan dengan simbol $j$ [13].

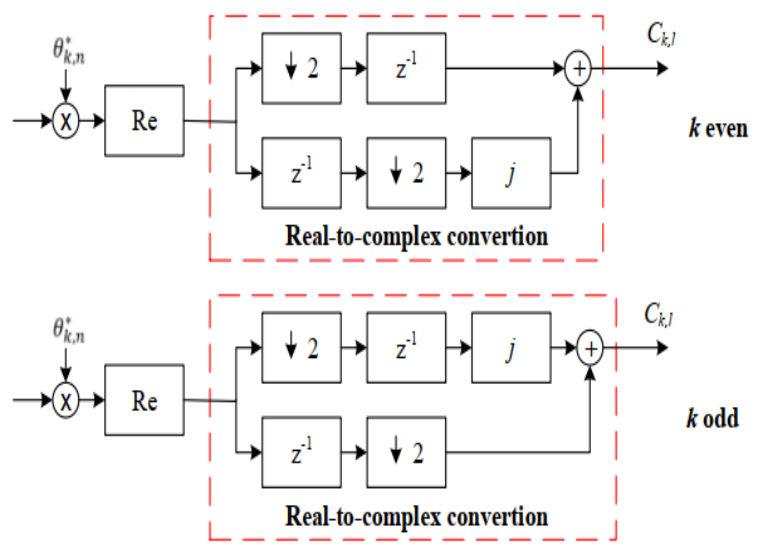

Gambar 5. Pasca Pengolahan OQAM [13]

\subsection{Zero Forcing (ZF)}

Zero forcing merupakan salah satu jenis ekualisasi yang cukup sederhana dan mudah dimana $\boldsymbol{H}$ adalah suatu matriks kanal dan $\boldsymbol{W}$ adalah matriks yang merepresentasikan proses linear pada penerima, sehingga persamaan ZF memenuhi syarat sebagai berikut [14]:

$$
W H=1
$$

Agar setiap elemen yang dihasilkan dari simbol dapat terdeteksi maka diperlukan adanya proses "memaksa" interferensi menjadi nol. Matriks W adalah matriks kebalikan dari matriks kanal $\boldsymbol{H}$. Seperti ditunjukkan pada persamaan berikut [14]:

$W_{Z F}=H^{-1}$ untuk $N_{T X}=N_{R X}$

$W_{Z F}=\left(H^{H} H\right)^{-1} H^{H}$ untuk $N_{T X} \neq N_{R X}$

dengan $\boldsymbol{H}^{H}$ merupakan konjugat transpos matriks $\boldsymbol{H}$. Pseudo Invers (PI) ada apabila jumlah antena pengirim $\mathrm{N}_{\mathrm{TX}}$ lebih kecil atau sama dengan jumlah antena pengirim $\left(\mathrm{N}_{\mathrm{RX}}\right)$, sedangkan untuk $\mathrm{N}_{\mathrm{TX}}$ yang lebih besar dari $\mathrm{N}_{\mathrm{RX}}$, maka $\boldsymbol{H}^{\boldsymbol{H}} \boldsymbol{H}$ bernilai singular sehingga kebalikannya tidak terdefinisi.

Untuk menghitung kapasitas kanal pada sistem antena SISO menggunakan teori Shannon dengan SNR adalah perbandingan sinyal terhadap derau (dalam bentuk perbandingan linear), maka persamaannya adalah [15]:

$$
\mathrm{C}=\log _{2}[1+(\mathrm{SNR})] \mathrm{bps} / \mathrm{Hz}
$$

dengan $\mathrm{C}$ adalah kapasitas kanal (bps/Hz)

\section{Hasil dan Analisis}

\subsection{Data Keluaran}

Penelitian ini disimulasikan menggunakan Matlab 2018b. Pengujian data keluaran menggunakan aplikasi Scan QR code untuk membaca informasi didalamnya.

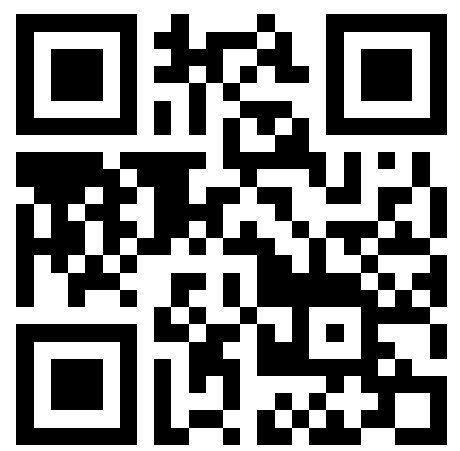

Gambar 6. Data Masukan

Data masukan sebagaimana yang dapat dilihat pada Gambar 6 menggunakan adalah citra QR code dengan dimensi 80 x 80 pixels. Data masukan memiliki informasi berupa teks 
1069986\&QR=1148403\&I=MAF. Data masukan selanjutnya akan dikonversi menjadi bentuk biner. Untuk dapat menghasilkan nilai biner, data masukan harus dikonversi terlebih dahulu dalam bentuk citra grayscale sebelum dikonversi menjadi bit biner.

Dari data masukan tersebut kemudian diolah pada sistem FBMC OQAM. Sama halnya dengan data masukan, pada hasil data keluaran yang dihasilkan oleh simulasi juga harus dikembalikan menjadi bentuk awal. Proses ini dinamakan proses rekonstruksi data masukan. Hasil data keluaran dapat dilihat pada Gambar 7 sampai Gambar 9.

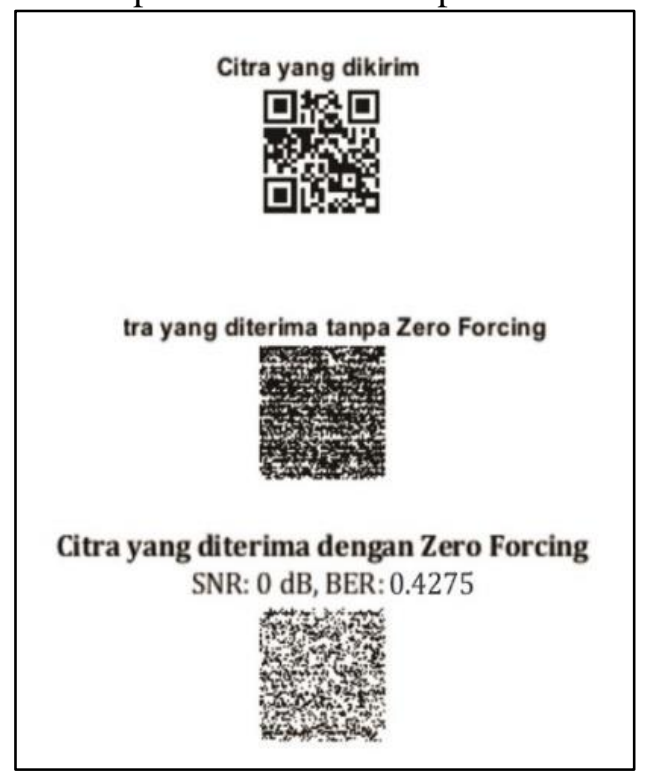

Gambar 7. Data Keluaran SNR 0 dB

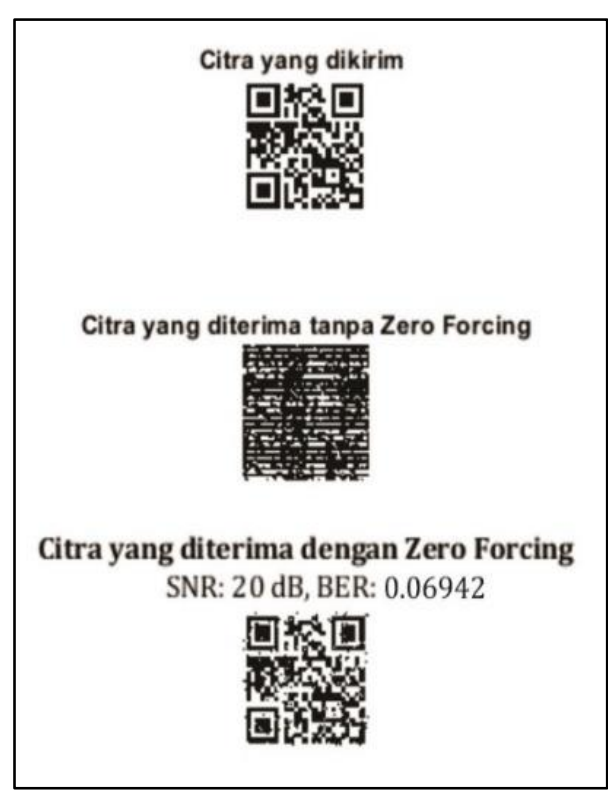

Gambar 8. Data Keluaran 20 dB

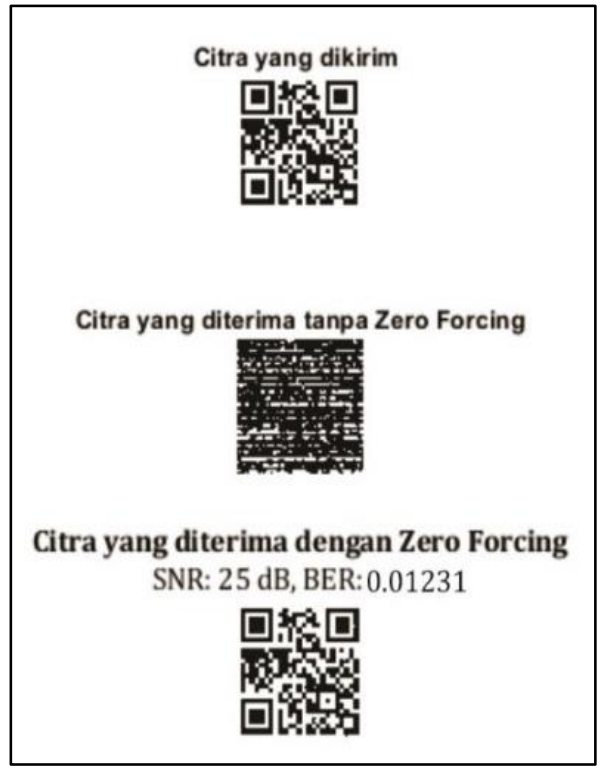

Gambar 9. Data Keluaran 25 dB

Simulasi ini menggunakan variasi level SNR dari rentang $0 \mathrm{~dB}$ sampai $25 \mathrm{~dB}$. Dari hasil data keluaran yang dihasilkan, tidak semua hasil data keluaran dapat terbaca informasi didalamnya.

Batas nilai data keluaran yang bisa terbaca informasi dengan aplikasi adalah pada nilai SNR 23 dB. Hasil uji coba scan data keluaran dapat dilihat pada Gambar 10 berikut ini:
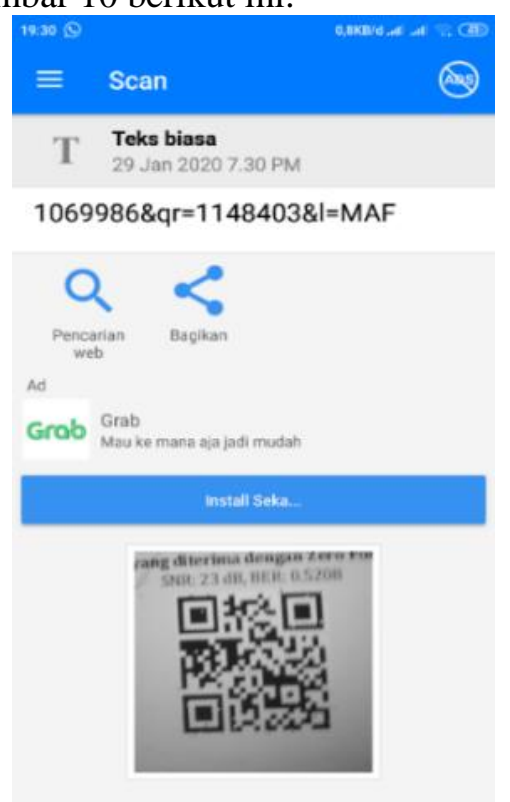

Gambar 10. Hasil Scan Data Keluaran 23 dB

\subsection{Pengujian Parameter}

\subsubsection{Sistem FBMC OQAM}

Pada pengujian simulasi sistem FBMC OQAM, data yang dikirimkan oleh pengirim dan diterima oleh sisi penerima merupakan hasil dari perkalian 
anatara sinyal yang dikirimkan dengan kanal yang ditambahkan dengan derau. Pada pengujian ini belum menggunakan ekualisasi apapun yang digunakan. Karakteristik BER terhadap perubahan SNR dapat dilihat pada Gambar 11 berikut ini:

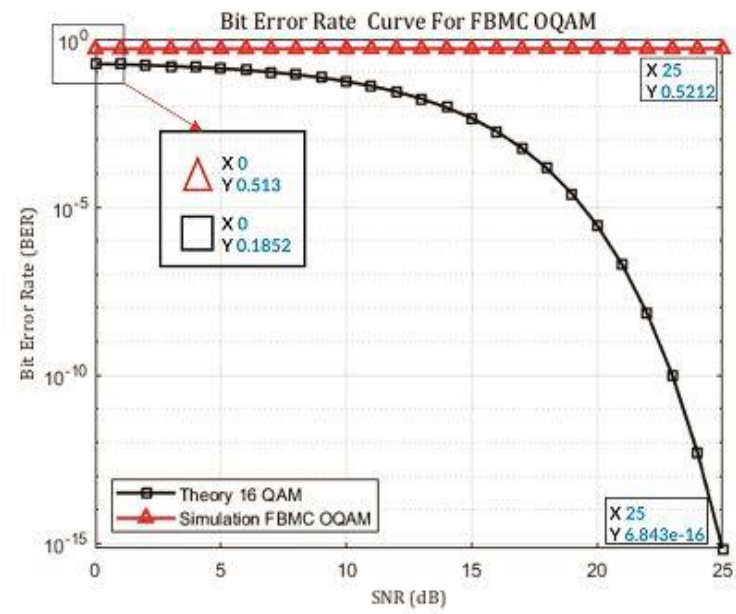

Gambar 11. Karakter BER Pada FBMC OQAM

Berdasarkan Gambar 11 dapat diketahui bahwa besar nilai BER yang dihasilkan ketika simulasi memiliki kualitas yang kurang baik. Seperti dapat dilihat pada nilai SNR $0 \mathrm{~dB}$ menghasilkan nilai BER sebesar 0,513 dan ketika nilai SNR $25 \mathrm{~dB}$, maka nilai BER simulasi yang dihasilkan adalah sebesar 0,5212. Nilai BER dari setiap SNR cukup stabil nilainya. Hal ini karena adanya kanal AWGN yang yang sudah ditambahkan derau dengan nilai 5 dB. Sehingga berapapun nilai SNR tidak berpengaruh banyak pada BER yang dihasilkan.

\subsubsection{Sistem FBMC OQAM ZF}

Simulasi ini adalah simulasi komunikasi FBMC OQAM dengan masukan citra $Q R$ code dengan ditambahkan blok ekualisasi. Ekualisasi yang digunakan adalah jenis Zero Forcing. Perbandingan SNR dengan BER dapat ditunjukkan pada Gambar 12 berikut ini:

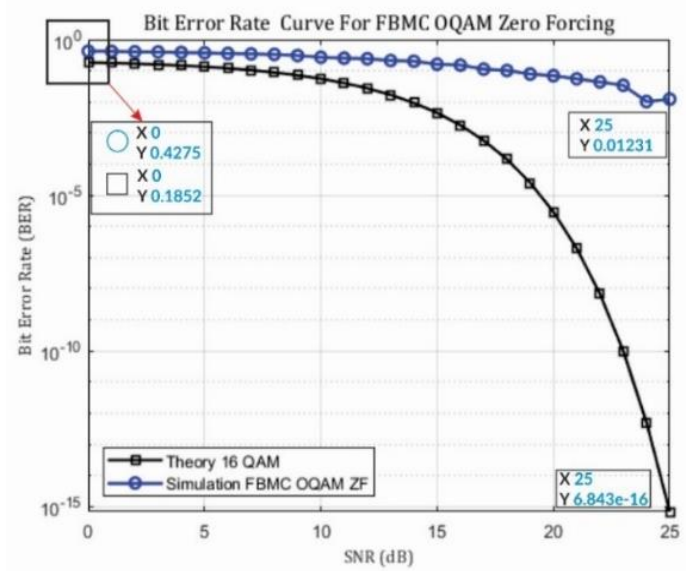

Gambar 12. Perbandingan SNR terhadap BER Pada FBMC dengan Ekualisasi ZF

Berdasarkan Gambar 12 penggunaan ekualisasi Zero forcing sedikit lebih baik jika tanpa ekualisasi. Pada SNR $0 \mathrm{~dB}$ nilai BER yang dihasilkan adalah 0,4275 dan pada SNR $25 \mathrm{~dB}$ nilai BER yang dihasilkan adalah 0,01231. Dari nilai tersebut, terbukti sedikit lebih baik yaitu dalam hal nilai BER yang dihasilkan. Nilai SNR 0 dB sampai SNR 25 $\mathrm{dB}$ dapat menurunkan nilai BER dari 0,4275 menjadi 0,01231 .

Perbandingan SNR terhadap SER ditunjukkan pada Gambar 13. Hasil perbandingan BER sebanding dengan hasil perbandingan SER (Simbol Error Rate), yakni nilai SER untuk FBMC OQAM tanpa menggunakan ekualisasi saat SNR $0 \mathrm{~dB}$ sebesar 0,9592 dan jika menggunakan ekualisasi ZF hasilnya sebesar 0,8003 . Hal ini dikarenakan Nilai Ps (probabilitas kesalahan simbol, SER) sebanding lurus dengan $\mathrm{Pb}$ (probabilitas kesalahan bit, BER).

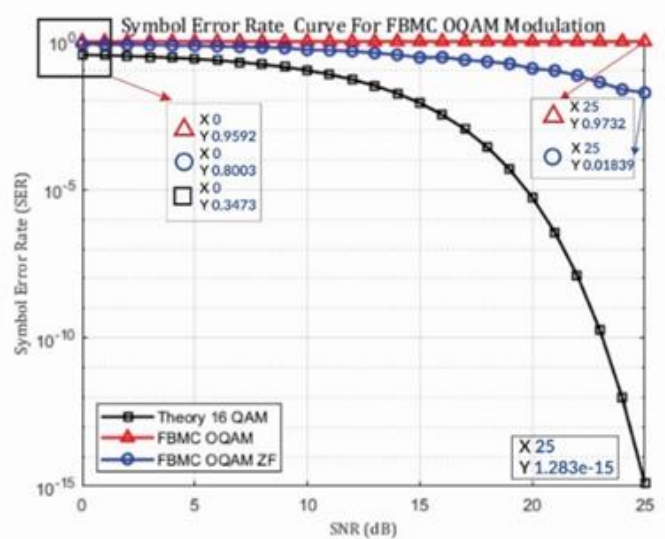

Gambar 13. Perbandingan SNR terhadap SER 


\subsubsection{Perbandingan FBMC OQAM dan FBMC OQAM ZF}

Perbandingan BER FBMC OQAM dengan BER FBMC OQAM ZF dalam hasil simulasi dapat dilihat pada Gambar 14 berikut ini:

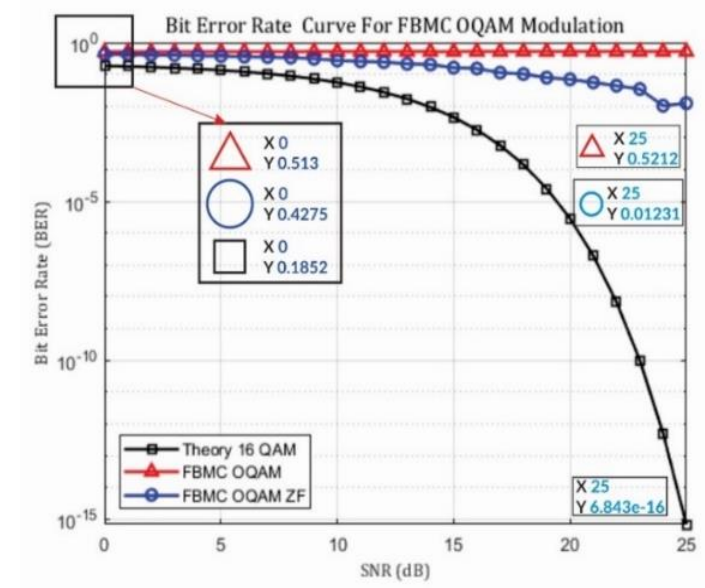

Gambar 14. Perbandingan

BER

FBMC Dengandan Tanpa Ekualisasi ZF

Berdasarkan Gambar 14, nilai BER FBMC OQAM yang dihasilkan dari SNR $0 \mathrm{~dB}$ adalah 0,513, sampai SNR 25 dB memiliki BER 0,5212. Sedangkan BER FBMC OQAM ZF pada nilai SNR $0 \mathrm{~dB}$ adalah 0,4275 dan pada SNR $25 \mathrm{~dB}$ memiliki nilai BER sebesar 0,01231. Dapat dilihat juga FBMC OQAM dengan ekualisasi Zero forcing memiliki penurunan BER yang cukup signifikan. FBMC OQAM ZF terbukti bahwa nilai SNR yang meningkat akan berpengaruh pada nilai BER yang semakin mengecil. Dengan menggunakan ekualisasi Zero forcing dapat mengembalikan sinyal asli yang dikirim walaupun sinyal informasi tersebut sudah tercampur dengan derau, sedangkan jika tanpa menggunakan ekualisasi, sinyal-sinyal informasi yang dikirimkan oleh antena pengirim akan dikirimkan secara langsung ke antena penerima dan mengandung banyak derau didalamnya. Derau ini didapatkan dari kanal Additive White Gaussian Noise (AWGN). Nilai derau diperoleh secara acak dan juga ditambahkan sesuai perancangan simulasi.

\subsubsection{Pengujian Kapasitas Kanal}

Kapasitas kanal digunaka untuk mengetahui seberapa besar bandwidth maksimum yang dapat dilewatkan oleh antena pengirim dan antena penerima untuk transmisi sinyal informasi Hasil pengujian kapasitas kanal dari simulasi FBMC
OQAM dengan data masukan citra $Q R$ code dapat dilihat pada Gambar 15 berikut ini:

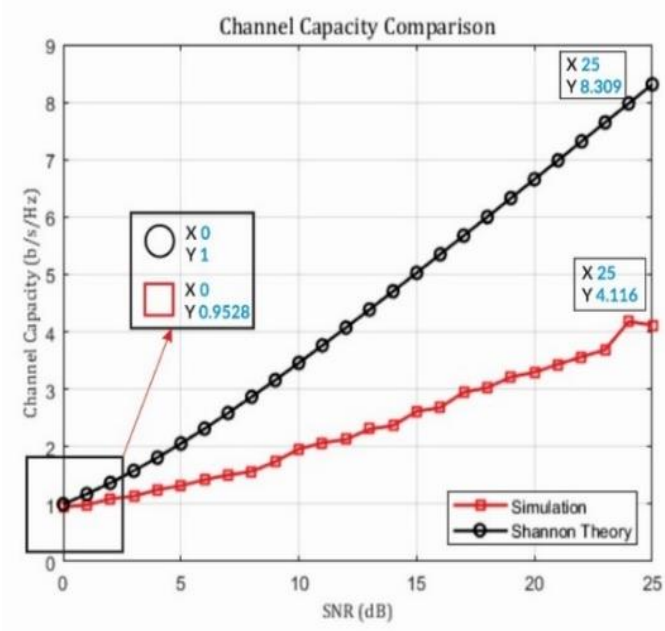

Gambar 15. Pengujian Kapasitas Kanal

Berdasarkan Gambar 14 di atas, dapat disimpulkan kapasitas kanal yang tersedia sudah cukup meningkat dari nilai $0,9528 \mathrm{~b} / \mathrm{s} / \mathrm{Hz}$ pada SNR $0 \mathrm{~dB}$ sampai nilai 4,116 b/s/Hz pada SNR 25 dB. Kapasitas kanal yang dihasilkan sudah cukup baik, meskipun masih jauh dari pada kanal Shannon. Hal ini bisa terjadi karena adanya derau yang bersifat acak serta tidak dapat dihindarkan.

\section{Kesimpulan}

Dari hasil analisis dapat disimpulkan bahwa dengan menggunakan ekualisasi Zero forcing (ZF), Sistem FBMC-OQAM mampu menekan nilai BER dari nilai 0,4275 pada SNR $0 \mathrm{~dB}$ sampai nilai 0,01231 pada SNR $25 \mathrm{~dB}$ dibandingkan dengan sistem tanpa ekualisasi. Sementara batas nilai SNR yang dapat terbaca informasi didalamnya dengan aplikasi scan QR Code mulai dari SNR $23 \mathrm{~dB}$, dan Nilai SNR akan berbanding lurus dengan kapasitas kanal, semakin besar nilai SNR maka semakin besar kapasitas kanal yang digunakan.

\section{Ucapan Terima Kasih (Acknowledgement)}

Terima kasih disampaikan kepada LPPM Institut Teknologi Telkom Purwokerto untuk pendanaan dalam proses publikasi jurnal ini.

\section{Daftar Pustaka}

[1] J. Hendry and A. F. Isnawati, "Analisis Perbandingan Kinerja Ekualisasi Zero forcing dan MMSE pada FBMC-OQAM," ELKOMIKA J. Tek. Energi Elektr. Tek. Telekomun. Tek. Elektron., vol. 7, no. 3, p. 
600, Sep. 2019, doi: 10.26760/elkomika. V $7 \mathrm{i} 3.600$.

[2] M. L. Hakim and I. Santoso, "Analisis Kinerja Sistem MIMO-OFDM pada Kanal Rayleigh dan AWGN dengan Modulasi QPSK," p. 5, 2010,

[3] S. Kaur, L. Kansal, G. S. Gaba, and N. Safarov, "Survey of Filter Bank Multicarrier (FBMC) as an efficient waveform for 5G," $p$. 7.

[4] A. J. Ramadhan, "Implementation of $5 \mathrm{G}$ FBMC PHYDYAS Prototype Filter," vol. 12, no. 23, p. 7, 2017].

[5] P. Kansal and A. K. Shankhwar, "FBMC vs OFDM Waveform Contenders for $5 \mathrm{G}$ Wireless Communication Sistem," Wirel. Eng. Technol., vol. 08, no. 04, pp. 59-70, 2017.

[6] F. H. Ramadiansyah, "Generalized Frequency Division Multiplexing Dengan Menggunakan Offset Quadrature Amplitude," 2017.

[7] W. Khrouf, M. Siala, and F. Abdelkefi, "How Much FBMC/OQAM Is Better than FBMC/QAM? A Tentative Response Using the POPS Paradigm," Wirel. Commun. Mob. Comput., vol. 2018, no. December 2017, 2018.

[8] S. K. Bandari, V. V. Mani, and A. Drosopoulos, "OQAM implementation of GFDM," 2016 23rd Int. Conf. Telecommun. ICT 2016, 2016, doi: 10.1109/ICT.2016.7500463]

[9] B. Kamislioglu and A. Akbal, "ZF and MMSE application for FBMC-QAM," IDAP 2017 Int. Artif. Intell. Data Process. Symp., no. 1, pp. $\quad 1-5, \quad 2017, \quad$ doi: 10.1109/IDAP.2017.8090224].

[10] T. Lotlikar, R. Kankapurkar, A. Parekar, and A. Mohite, "Comparative study of Barcode, QR-code and RFID System," vol. 4, p. 5, 2013.

[11] K. Petrova, A. Romaniello, B. D. Medlin, and S. A. Vannoy, "QR Codes Advantages and Dangers:," in Proceedings of the 13th International Joint Conference on e-Business and Telecommunications, Lisbon, Portugal, 2016, pp. 112-115, doi: $10.5220 / 0005993101120115$.

[12] S. Jo and J.-S. Seo, "Tx scenario analysis of FBMC based LDM sistem," ICT Express, vol. 1, no. 3, pp. 138-142, Dec. 2015.

[13] A. F. Isnawati, V. O. Citra, and J. Hendry, "Performance Analysis of Audio Data
Transmission on FBMC - Offset QAM System," in 2019 IEEE International Conference on Industry 4.0, Artificial Intelligence, and Communications Technology (IAICT), BALI, Indonesia, 2019, pp. 81-86, doi: 10.1109/ICIAICT.2019.8784810.

[14] R. Hidayat, A. F. Isnawati, and B. Setiyanto, "Channel estimation in MIMO-OFDM spatial multiplexing using Least Square method," in 2011 International Symposium on Intelligent Signal Processing and Communications Systems (ISPACS), 2011, pp. 1-5.

[15] A. F. Isnawati, "Unjukkerja Sistem MIMOOFDM Penjamakan Spasial Menggunakan Estimasi Kanal," Universitas Gajah Mada, 2011.

\section{Biodata Penulis}

Brayan Raynaldi, lahir di Banyumas, 13 Februari 1998. Lulusan Institut Teknologi Telkom Purwokerto pada tahun 2020. Saat ini bekerja sebagai IT Project Officer bidang Computing License \& QA Management di PT. Bank Rakyat Indonesia (Persero) Tbk.

Anggun Fitrian Isnawati, lahir di Cilacap, 4 September 1978. Memperoleh gelar Magister Teknik Telekomunikasi (M.Eng) pada tahun 2011 dan Doktor (Dr.) pada tahun 2018 dari Departemen Teknik Elektro dan Teknologi Informasi, Fakultas Teknik Universitas Gadjah Mada, Yogyakarta. Bergabung sebagai Dosen di Institut Teknologi Telkom Purwokerto (IT Telkom Purwokerto) sejak tahun 2002. Minat penelitiannya meliputi wireless communication, cellular communication, game theory, dan cognitive radio.

Mas Aly Afandi, lahir di Surabaya, 17 Mei 1993. Memperoleh gelar Sarjana Sains Terapan (S.ST) dari Politeknik Elektronika Negeri Surabaya pada tahun 2015. Memperoleh gelar Magister Teknik dari Institut Teknologi Sepuluh Nopember pada tahun 2018. Bergabung sebagai Dosen di Institut Teknologi Telkom Purwokerto pada tahun (2019). Minat penelitian meliputi Artificial Intelligence, Computer Vision, Mathematics, Physics, Internet of Things, dan Applied Electronics. 